\title{
Compositions of unsaturated polyester resins used for facing layers of laminates (Rapid communication)
}

\author{
Rafał Oliwa ${ }^{1)}$ \\ DOI: dx.doi.org/10.14314/polimery.2020.10.9
}

\begin{abstract}
Hybrid composites of unsaturated polyester resin with the addition of glass microspheres and bentonite modified with a quaternary ammonium salt were obtained. The content of bentonite in composites was $3 \mathrm{wt} \%$, while glass microspheres varied in the range of $5-15 \mathrm{wt} \%$. The effect of the addition of glass microspheres on the rheological and mechanical properties of unsaturated polyester resin composites containing modified bentonite was investigated. On the basis of the obtained results, it was found that the optimum content of glass microspheres in polyester composites at which a clear increase in the value of most mechanical parameters was achieved, is $15 \mathrm{wt} \%$. The Young's modulus, flexural modulus, tensile strength, and Charpy impact strength increased by $14.7,38.7,17.7$ and $25 \%$, respectively, compared to the unmodified resin. On the other hand, with relation to the sample containing $3 \mathrm{wt} \%$ of bentonite, a significant improvement was achieved only in the case of the flexural modulus and impact strength, amounting to 16.5 and $36.0 \%$, respectively. In addition, composite with $15 \mathrm{wt} \%$ of glass microspheres was characterized by a smaller, by about $25 \%$, flexural strength in relation to the unfilled resin and resin with $3 \mathrm{wt} \%$ of bentonite. In turn, rheological studies have shown that as the content of glass microspheres increased, there was an increase in viscosity and a decrease in gelation time in relation to the reference sample and the sample with $3 \mathrm{wt} \%$ of bentonite.
\end{abstract}

Keywords: unsaturated polyester resin, hollow glass microspheres, organoclay, mechanical properties, rheological behavior.

\section{Kompozycje nienasyconych żywic poliestrowych stosowane na warstwy licowe laminatów}

Streszczenie: Otrzymano hybrydowe kompozyty nienasyconej żywicy poliestrowej z dodatkiem mikrosfer szklanych oraz bentonitu modyfikowanego czwartorzędową solą amoniową. Zawartość bentonitu w kompozytach wynosiła 3\% mas., natomiast udział mikrosfer szklanych zmieniał się w zakresie 5-15\% mas. Zbadano wpływ dodatku mikrosfer szklanych na właściwości reologiczne oraz mechaniczne kompozytów nienasyconej żywicy poliestrowej zawierających modyfikowany bentonit. Stwierdzono, że optymalna zawartość mikrosfer szklanych w kompozytach poliestrowych wynosi 15\% mas., kompozyty z taką zawartością mikrosfer wykazują wyraźną poprawę większości właściwości mechanicznych. Wartości modułu Younga, modułu elastyczności, naprężenia zrywającego, udarności wg Charpy'ego oraz twardości zwiększyły się o, odpowiednio, 14,7; 38,7; 17,7 oraz 25\%, w porównaniu z odpowiednimi wartościami odnoszącymi się do niemodyfikowanej żywicy. Natomiast w wypadku próbki zawierającej $3 \%$ mas. bentonitu uzyskano istotne zwiększenie jedynie modułu elastyczności i udarności, wynoszące, odpowiednio, 16,5 oraz $36,0 \%$. Kompozyty z zawartością 15\% mas. mikrosfer szklanych charakteryzowały się mniejszym, o ok. $25 \%$, naprężeniem zginającym niż żywica nienapełniona i żywica z udziałem $3 \%$ mas. bentonitu. Badania reologiczne wykazały, że wraz ze wzrostem zawartości mikrosfer szklanych w kompozycji nastąpiło zwiększenie lepkości oraz skrócenie czasu żelowania w odniesieniu do odpowiednich wartości próbki referencyjnej i próbki z 3\% mas. bentonitu.

Słowa kluczowe: nienasycona żywica poliestrowa, mikrosfery szklane, organobentonit, właściwości mechaniczne, właściwości reologiczne.

1) Rzeszow University of Technology, Department of Polymer Composites, al. Powstańców Warszawy 6, 35-959 Rzeszów, Poland; e-mail: oliwa@prz.edu.pl 
Glass balls, also called microbubbles or microspheres, have a diameter in the range of 1 to 200 microns and a small wall thickness, which is from 1 to $10 \%$ of the diameter of the spheres. The inside of the spheres is filled with gas, which results in their low apparent density, with good specific strength, corrosion resistance, wear resistance and low thermal conductivity. In addition, they are made of bromo-silicon glass, which makes them chemically inert. Due to this facts, glass microspheres have many applications in the processing of plastics, among others, to reduce the mass of products in which the content of glass microballoons reaches $40-60 \%$ creating syntactic foams [1-3], reduce the thermal conductivity of plastics [4, 5], improve dielectric properties [6], acoustic properties [7] or as flame retardant additives [3, 8]. However, the mechanical properties of polymer composites decrease, with glass microsphere loading $[5,9,10]$. To reduce this negative effect, various enhancements in the form of nanoparticles such as nanoclay [11-13], graphene [14] and carbon nanotubes [15] are introduced. However, these works focused only on syntactic foams containing glass bubbles at the rate of 30-60 wt \%. In addition, there is no information on hybrid unsaturated polyester resin composites containing smaller amounts of glass microspheres and nanoclays. Therefore, based on our previous research on the modification of polymer resins with the addition of modified aluminosilicates, we have attempted to obtain hybrid unsaturated polyester resin composites containing modified aluminosilicates and glass microspheres used as facing layers of laminates.

\section{EXPERIMENTAL PART}

\section{Materials}

The following materials were used in this study:

- Unsaturated polyester resin with the trade name Polimal 1099 P (UP) from Ciech Sarzyna;

- Curing agent Luperox K-1S from ARKEMA Sp. z o.o.;

- GS60 glass microspheres (density $0.60 \mathrm{~g} / \mathrm{cm}^{3}, D_{10}$ $=25 \mu \mathrm{m}, D_{50}=43 \mu \mathrm{m}, D_{90}=85 \mu \mathrm{m}$, from WTH $(\mathrm{GmbH}$, Germany);

- Bentonite (BS) Specjal (Zębiec S.A. Plants, Poland) modified with a benzyl C12-C14-alkyldimethylammonium chloride (BSQAS, $d_{\mathrm{hkl}}=29.6 \AA$ ) [16]. The procedure of modifying smectic clays with quaternary ammonium salts had been previously patented $[17,18]$ and described in detail in our previous papers [16].

\section{Preparation unsaturated polyester composites}

As part of the study, four different compositions were prepared containing modified bentonite and glass microspheres. The compositions selected are listed in Table 1.

Composition of the unsaturated polyester resin containing $3.0 \mathrm{wt} \%$ of bentonite Specjal modified QAS have been prepared using four step homogenization proce-
$\mathrm{T}$ a b l e 1 . Unsaturated polyester resin compositions with additives (wt \%)

\begin{tabular}{c|c|c|c}
\hline $\begin{array}{c}\text { Symbol of } \\
\text { sample }\end{array}$ & UP & GS60 & BSQAS \\
\hline K0 & 100 & 0 & 0 \\
K1 & 97 & 0 & 3 \\
K2 & 92 & 5 & 3 \\
K3 & 87 & 10 & 3 \\
K4 & 82 & 15 & 3 \\
\hline
\end{tabular}

dure [17]. For compositions 2-4, after mixing the bentonite, the remaining amount of glass microspheres were introduced and mixed again with a high shear mixer (Dispermat CN40 produced by VMA-Getzmann, $\mathrm{GmbH}$ ) for 10 minutes, at velocity of $1500 \mathrm{rpm}$, where a propeller mixer was applied as a homogenizing element. Then, the compositions were vented using a VAKUUM UHG 400 chamber (Schuechl, Germany). Some compositions were used for rheological studies. From the remaining $200 \mathrm{~g}$ of each composition, a samples for mechanical testing were obtained. To this end, $1 \mathrm{wt} \%$ of initiator was added and then cast at room temperature into silicone molds prepared in accordance with ISO 527-1:1998. The samples were cured at room temperature for $24 \mathrm{~h}$ and then cured at $80^{\circ} \mathrm{C}$ for $2 \mathrm{~h}$. After two days, the composites were tested in accordance with standards.

\section{Methods of testing}

\section{Mechanical properties}

Tensile strength was studied according to ISO 527-1:1998 standard using Instron 5967 testing machine. Elongation speed was $2 \mathrm{~mm} / \mathrm{min}$.

The bending tests were performed according to PN-EN ISO 178, using the same tensile machine equipped with a three point bending rig. The vertical displacement speed of the rig during the test was $2 \mathrm{~mm} / \mathrm{min}$.

Rockwell hardness was tested with ZWICK 3106 hardness tester, in accordance with EN 10109-1 standard. Indenter load equaled $358 \mathrm{~N}$.

Charpy impact resistance was determined according to PN-EN ISO 179-1 with Ceast 9050 Impact Pendulum (Italy), using hammer impact energy of $1 \mathrm{~J}$.

\section{Rheological properties}

Flow curves of non-hardener polyester compositions were made using a HAAKE RheoStress 6000 (Thermo Fisher Scientific, USA) rotatory rheometer with the RheoWin Job Manager control program, using a coneplate system $\mathrm{C} 35 / 1^{\circ}$, at $23 \pm 0.1^{\circ} \mathrm{C}$, in the shear rate range of $1.0-600 \mathrm{~s}^{-1}$.

Reactivity studies on polyester compositions after the addition of $1 \%$ initator were assessed by determining the gel time using Discovery HR-2 rheometer, equipped with 
a temperature control system in the upper and lower part of the measuring system. The measurements were carried out in plate-plate diameter $25 \mathrm{~mm}$, using the following conditions: the width of the measuring gap $-1 \mathrm{~mm}$, oscillation frequency $-1 \mathrm{~Hz}$, deformation 0.05 .

\section{RESULTS AND DISCUSSION}

Based on the obtained viscosity curves, the viscosity value was determined for the initial shear rate $\eta_{1}$ and for $600 \mathrm{~s}^{-1} \eta_{600}$ (Fig. 1).

By analyzing the viscosity curves in Fig. 1, it can be seen that the polyester resin compositions are characterized by increased viscosity. In the case of a composition containing 3 wt \% of modified bentonite, the viscosity increased more than twofold compared to the unfilled polyester resin $-\eta_{1}=0.5250 \mathrm{~Pa} \cdot \mathrm{s}$ (instead of $0.2133 \mathrm{~Pa} \cdot \mathrm{s}$ - K0), $\eta_{600}=0.3339$ Pa.s (instead of 0.2128 Pa.s - K0). In addition, it was observed that the additional introduction of glass microspheres up to $10 \mathrm{wt} \%$ causes a gradual increase in viscosity $\left(\eta_{1}=1.2524-1.2613\right.$ Pa.s, $\eta_{600}=0.8478$ $0.8556 \mathrm{~Pa} \cdot \mathrm{s}$. In turn, the composition containing 3 wt \% of BSQAS and $15 \mathrm{wt} \%$ of GS60 is already characterized by a sharp increase in the tested property, because the viscosity at shear rate 1 and $600 \mathrm{~s}^{-1}$ was 3.4194 and $1.7928 \mathrm{~Pa} \cdot \mathrm{s}$, respectively. The viscosity values are much higher than the data obtained by the Kang team, who used glass microspheres with smaller diameters in the range of $20-48 \mu \mathrm{m}$ [19]. In addition, this may be due to the additional bentonite content which is advantageous from the point of application of these compositions as composite facing layers. The shear-thinning behavior of unsaturated polyester compositions is confirmed by the viscosity loops, where a viscosity decreases with the

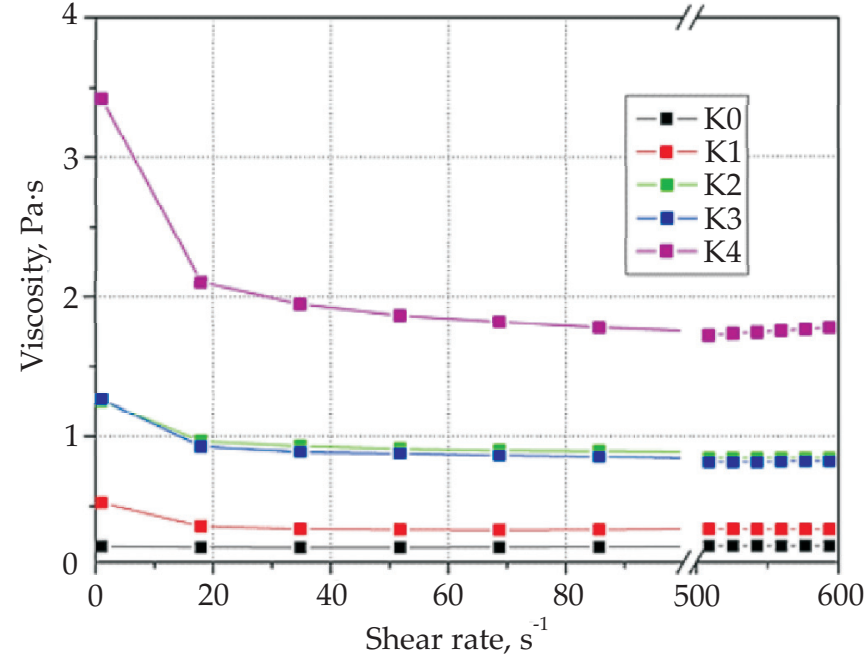

Fig. 1. Viscosity curves of unsaturated polyester resin compositions

increase in shear rate. Only, as might have been expected, the unfilled resin maintains the similar viscosity over the wide range of shear rates.

As a results of the gel time study, the values of the loss modulus $G^{\prime \prime}$, storage modulus $G^{\prime}$, complex dynamic viscosity $\eta^{*}$ and loss tan $\delta$ from the time $t_{\mathrm{s}}$ were obtained (Table 2). The gel time was determined on the basis of the intersection of the curves $G^{\prime}$ and $G^{\prime \prime}$ [20].

On the basis of the obtained results, it was found that the addition of modified bentonite causes a slight increase in gelation time by approx. $15 \%$ compared to the unfilled resin, which is opposite to the literature data [21, 22]. In turn, the introduction of glass microspheres causes the shift of the intersection point of the curves $G^{\prime}$ and $G^{\prime \prime}$ towards smaller values of gelation time. Interestingly,

T a b l e 2. Results of gelation properties of unsaturated polyester resin compositions containing glass microsphere and modified bentonite

\begin{tabular}{c|c|c|c|c|c}
\hline Symbol of sample & $\begin{array}{c}\text { Viscosity } \eta \text { at the } \\
\text { gelation point } \\
\text { Pa·s }\end{array}$ & $\begin{array}{c}\text { Gel time } \\
\mathrm{s}\end{array}$ & $\begin{array}{c}\text { Initial } G^{\prime} \\
\text { Pa }\end{array}$ & $\begin{array}{c}\text { Initial } G^{\prime \prime} \\
\text { Pa }\end{array}$ & $\begin{array}{c}G^{\prime}=G^{\prime \prime} \text { at the } \\
\text { gelation point } \\
\text { Pa }\end{array}$ \\
\hline K0 & 3.817 & 679.646 & 1.125 & 1.928 & 16.1896 \\
K1 & 26.898 & 778.145 & 1.136 & 1.928 & 115.866 \\
K2 & 45.198 & 419.001 & 1.465 & 11.416 & 193.116 \\
K3 & 54.093 & 424.102 & 1.625 & 14.653 & 238.283 \\
K4 & 75.142 & 398.815 & 2.676 & 17.139 & 411.822 \\
\hline
\end{tabular}

$\mathrm{T}$ a b l e 3. Mechanical properties of unsaturated polyester resin compositions containing glass microsphere and modified bentonite

\begin{tabular}{c|c|c|c|c|c|c}
\hline $\begin{array}{c}\text { Symbol of } \\
\text { sample }\end{array}$ & $\begin{array}{c}\text { Ultimate flexural } \\
\text { strength } \\
\mathrm{MPa}\end{array}$ & $\begin{array}{c}\text { Flexural } \\
\text { modulus } \\
\mathrm{GPa}\end{array}$ & $\begin{array}{c}\text { Ultimate tensile } \\
\text { strength } \\
\mathrm{MPa}\end{array}$ & $\begin{array}{c}\text { Young's } \\
\text { modulus } \\
\mathrm{GPa}\end{array}$ & $\begin{array}{c}\text { Charpy impact } \\
\mathrm{kJ} / \mathrm{m}^{2}\end{array}$ & $\begin{array}{c}\text { Rockwell } \\
\text { hardness } \\
\mathrm{MPa}\end{array}$ \\
\hline K0 & $90.8 \pm 2.4$ & $3.10 \pm 0.31$ & $43.0 \pm 3.3$ & $2.45 \pm 0.13$ & $1.36 \pm 0.18$ & $149.2 \pm 15.9$ \\
K1 & $96.7 \pm 7.2$ & $3.69 \pm 0.29$ & $54.4 \pm 4.0$ & $2.75 \pm 0.16$ & $1.25 \pm 0.07$ & $206.9 \pm 11.9$ \\
K2 & $59.8 \pm 2.6$ & $2.89 \pm 0.22$ & $37.4 \pm 2.1$ & $2.28 \pm 0.24$ & $1.12 \pm 0.05$ & $164.1 \pm 21.3$ \\
K3 & $60.5 \pm 7.1$ & $3.38 \pm 0.38$ & $42.9 \pm 4.4$ & $2.42 \pm 0.23$ & $1.58 \pm 0.13$ & $158.4 \pm 7.9$ \\
K4 & $60.2 \pm 6.6$ & $4.30 \pm 0.41$ & $50.6 \pm 3.6$ & $2.81 \pm 0.26$ & $1.70 \pm 0.19$ & $152.9 \pm 7.6$ \\
\hline
\end{tabular}


regardless of their content, the gel time of compositions containing glass microspheres was on average 260 and 360 seconds shorter compared to compositions $\mathrm{K} 0$ and $\mathrm{K} 1$, respectively. However, a relationship between the amount of glass microspheres and the other parameters was observed, because with the increase in the content of glass microspheres, the viscosity at the gelation point and the values of the storage modulus $G^{\prime}$ and loss modulus $G^{\prime \prime}$ increased. As expected, the addition of $5 \mathrm{wt} \%$ of glass microspheres caused a rapid increase in the initial value of the loss modulus $G^{\prime \prime}$, which is associated with an increase in the viscosity of the composition. In turn, in the case of composition $\mathrm{K} 4$, a rapid increase in the initial and final value of the storage module was noted, which coincides with the results of rheological tests. This composition was also characterized by $185 \%$ higher viscosity at the gel point compared to a sample with $3 \mathrm{wt} \%$ of bentonite $\left(\eta_{\mathrm{K} 1}=26.8 \mathrm{~Pa} \cdot \mathrm{s}\right)$ (Table 3$)$.

Based on the obtained test results, it was found that the optimum content of glass microspheres in the polyester matrix at which there is a clear increase in mechanical properties is $15 \mathrm{wt} \%$ (Table 3 ). The $\mathrm{K} 4$ composite was characterized by the largest increase in stiffness because the flexural modulus increased by $16.5 \%$ compared to the composite containing only $3 \mathrm{wt} \%$ of bentonite, while Young's modulus was at the level of the K1 composite. However, with respect to the unfilled resin, the change was more pronounced because the flexural modulus and Young's modulus increased by 38.7 and $14.7 \%$, respectively. In addition, the composite containing $15 \mathrm{wt} \%$ of glass microspheres and 3 wt \% of bentonite had a tensile strength about $18 \%$ higher than UP. In turn, other composite containing $5 \mathrm{wt} \%$ of glass microspheres were characterized by a reduced value of Young's modulus and tensile strength in relation to UP, while the K3 composite had these parameters at the level of unmodified resin. Analyzing the impact values, it can be seen that the addition of bentonite causes a decrease in this value, while the additional introduction of glass microspheres in the range of $10-15 \mathrm{wt} \%$ leads to an improvement of this parameter compared to the K0 composite by 16 and 25\%, respectively. Once again, the least impact strength had a composite containing $5 \mathrm{wt} \%$ GS60. An inverse relationship was observed in the hardness test, since the composite having the highest hardness was $3 \mathrm{wt} \%$ of bentonite while, hardness decreased with GS60 loading. Despite this, all composites containing glass microspheres had a hardness at the level of unfilled resin. Among the parameters tested, the bending stress deteriorated, which decreased with the increase in the content of glass microspheres, which coincides with the literature data [9].

\section{SUMMARY}

The paper presents the results of research on the impact of the addition of bentonite and glass microspheres on the rheological and mechanical properties of unsaturated polyester resin composites. On the basis of the obtained results, it was found that the apparent viscosity and the shear-thinning behavior of compositions increase, with glass microspheres loading, which is beneficial in the context of using them as facing layers of laminates. In turn, the gelation time was shortened as the filler content increased. For mechanical properties, the tensile strength as well as the impact strength of the resin compositions filled with glass microspheres increased as the amount of filler increased. An inverse relationship was obtained for bending strength, while no significant changes were observed in the hardness tests.

\section{REFERENCES}

[1] Shunmugasamy V.C., Anantharaman H., Pinisetty D., Gupta N.: Journal of Composite Materials 2015, 49, 185. http://dx.doi.org/10.1177/0021998313515290

[2] Yu W., Qian M., Li H.: Journal of Applied Polymer Science 2016, 133, 44188. http://dx.doi.org/10.1002/app.44188

[3] Ding J., Liu Q., Ye F. et al.: Journal of Reinforced Plastics and Composites 2020, 39, 132. http://dx.doi.org/10.1177/0731684419877568

[4] Yang H., Jiang Y., Liu H. et al.: Journal of Colloid and Interface Science 2018, 530, 163.

http://dx.doi.org/10.1016/j.jcis.2018.06.075

[5] Huang C., Huang Z., Wang Q.: Polymer Engineering Science 2018, 58, 2200. http://dx.doi.org/10.1002/pen.24835

[6] Xu W., Na H., Zhao C.: Chemical Research in Chinese Universities 2018, 34, 862. http://dx.doi.org/10.1007/s40242-018-7419-4

[7] Gao G., Hu Y., Jia H. et al.: Journal of Physics and Chemistry of Solids 2019, 135, 109105. http://dx.doi.org/10.1016/j.jpcs.2019.109105

[8] Zhuo J., Xie L., Liu G. et al.: Journal of Thermal Analysis and Calorimetry 2017, 129, 357. http://dx.doi.org/10.1007/s10973-017-6142-6

[9] Hopmann C., Theunissen M., Haase S.: Journal of Polymer Engineering 2018, 38, 695. http://dx.doi.org/10.1515/polyeng-2017-0347

[10] Imran M., Rahaman A., Pal S.: Materials Research Express 2020, 7, 025307. http://dx.doi.org/10.1088/2053-1591/ab7164

[11] John B., Nair C.P.R., Ninan K.N.: Materials Science and Engineering: A 2010, 527, 5435. http://dx.doi.org/10.1016/j.msea.2010.05.016

[12] Maharsia R.R., Jerro H.D.: Materials Science and Engineering: A 2007, 454, 416. http://dx.doi.org/10.1016/j.msea.2006.11.121

[13] Woldesenbet E.: Materials Science and Engineering: A 2008, 496, 217. http://dx.doi.org/10.1016/j.msea.2008.05.024

[14] Zegeye E., Ghamsari A.K., Woldesenbet E.: Composites Part B: Engineering 2014, 60, 268. http://dx.doi.org/10.1016/j.compositesb.2013.12.040 
[15] Zhang X., Ya B., Huang B. et al.: Journal of Polymer Engineering 2017, 37, 93. http://dx.doi.org/10.1515/polyeng-2016-0001

[16] Oliwa R., Heneczkowski M., Oleksy M.: Polimery 2015, 60, 167.

http://dx.doi.org/10.14314/polimery.2015.167

[17] PL Pat. 395821 (2013).

[18] PL Pat. 397541 (2014).

[19] Kang Y., Lee W., Hwang J., Lee Y.: International Polymer Processing 2018, 33, 146. http://dx.doi.org/10.3139/217.3338
[20] Oliwa R., Oliwa J., Bulanda K. et al.: Polimery 2019, 64, 499.

http://dx.doi.org/10.14314/polimery.2019.7.5

[21] Naderi N., Mazinani S., Hosain Beheshty M., Mahdi Rajab M.: Plastics, Rubber and Composites 2015, 44, 19. http://dx.doi.org/10.1179/1743289814Y.0000000112

[22] Ramirez D., Gómez G., Jaramillo F.: Polymer Composites 2015, 36, 1931.

http://dx.doi.org/10.1002/pc.23101

Received 16 VI 2020. 